\title{
Correction to: Impact of Socioeconomic Status on Presentation and Outcomes in Colorectal Peritoneal Metastases Following Cytoreduction and Chemoperfusion: Persistent Inequalities in Outcomes at a High-Volume Center
}

Caroline J. Rieser, MD ${ }^{1}$ (D), Richard S. Hoehn, MD ${ }^{1}$, Mazen Zenati, MD, PhD ${ }^{1}$, Lauren B. Hall, MSc ${ }^{1}$, Eliza Kang, BS ${ }^{1}$, Amer H. Zureikat, MD ${ }^{1}$, Andrew Lee, MD ${ }^{1}$, Melanie Ongchin, MD ${ }^{1}$, Matthew P. Holtzman, $D^{1}$, James F. Pingpank, MD ${ }^{1}$, David L. Bartlett, $\mathrm{MD}^{2}$, and M. Haroon A. Choudry, MD ${ }^{1}$

${ }^{1}$ Division of Surgical Oncology, Koch Regional Perfusion Center, University of Pittsburgh, UPMC Cancer Pavilion, Pittsburgh, PA; ${ }^{2}$ AHN Cancer Institute, Allegheny Health Network, Pittsburgh, PA

\section{CORRECTION TO:}

ANN SURG ONCOL

HTTPS://DOI.ORG/10.1245/S10434-021-09627-2

In the original online version of the article there was an error in the legend in Fig. 1. The original article has been corrected.
Publisher's Note Springer Nature remains neutral with regard to jurisdictional claims in published maps and institutional affiliations.

The original article can be found online at https://doi.org/10.1245/ s10434-021-09627-2.

(C) The Author(s) 2021

Published Online: 23 April 2021

C. J. Rieser, MD

e-mail: riesercj2@upmc.edu 